\title{
Secretion of a putative metalloproteinase inhibitor by ovine granulosa cells and luteal tissue*
}

\author{
M. F. Smith $\dagger$ and R. M. Moor $\ddagger$ \\ $\uparrow$ Department of Animal Sciences, University of Missouri, Columbia, MO 65211, USA and \\ $\ddagger A F R C$ Institute of Animal Physiology and Genetics Research, Babraham, Cambridge CB2 4AT, UK
}

\begin{abstract}
Summary. Ovine granulosa cells respond, through transcriptional mechanisms, to preovulatory concentrations of gonadotrophins by secreting an $M_{\mathrm{r}} 30000$ polypeptide. To determine the stages of the oestrous cycle at which this polypeptide is secreted, corpora lutea were collected on Days 3, 7, 10,13 and 16 (Day $0=$ oestrus; $n=4$ per group), cut into $1-\mathrm{mm}$ slices, and incubated for $6-7 \mathrm{~h}$ with $\left[{ }^{35} \mathrm{~S}\right] \mathrm{methionine}$. Radiolabelled polypeptides of intra- and extra-cellular origin were separated by polyacrylamide gel electrophoresis and quantitated by densitometry. The $M_{\mathrm{r}} 30000$ polypeptide was secreted at all stages of the luteal phase tested (Days 3-16), and represented approximately $24 \%$ of the total labelled polypeptide present in the medium; polypeptides of approximate $M_{\mathrm{r}} 14000,25000$ and 46000 accounted for most of the other secreted proteins. Neither pituitary hormones (LH, FSH, prolactin) nor cholera toxin (chosen to activate adenylate cyclase) affected the rate of production of $M_{\mathrm{r}} 30000$ polypeptide, indicating that, once secretion has been initiated in the granulosa cells, it is not readily modulated by hormonal intervention after luteinization.

Incubation of luteinized granulosa cells with tunicamycin (inhibits $N$-linked glycosylation reactions) showed that the secreted polypeptide consists of a heavily glycosylated amino acid backbone of approximately $M_{\mathrm{r}} 20000$. Western blot analysis established further that the polypeptide was not an inhibin subunit. However, $\mathrm{NH}_{2}$ terminal amino acid sequencing of the first 25 amino acids revealed a $68 \%$ sequence identity between the secreted polypeptide $\left(M_{\mathrm{r}} 30000\right)$ and a human tissue inhibitor of metalloproteinases.
\end{abstract}

Keywords: granulosa cell; corpus luteum; polypeptide secretion; metalloproteinase inhibitor; sheep

\section{Introduction}

Ovarian cells secrete a variety of proteins which have an important endocrine, paracrine, or autocrine role in regulating reproductive function. Numerous studies have reported ovarian proteins which are involved in the regulation of mitosis, gonadotrophin binding, angiogenesis, luteinization and many other ovarian processes (Tsafriri, 1988).

The preovulatory gonadotrophin surge altered the pattern of follicular protein secretion in sheep (Moor \& Crosby, 1987). More specifically, when intact follicles or granulosa cells were exposed to gonadotrophins (in vivo or in vitro) the secretion of $M_{\mathrm{r}} 46000-60000$ polypeptides decreased over time, while that of an $M_{\mathrm{r}} 30000$ polypeptide was begun. Furthermore, inhibition of transcription in follicles after gonadotrophin stimulation inhibited synthesis of the $M_{\mathrm{r}} 30000$ polypeptide which is phosphorylated and glycosylated but not sulphated.

The results of Moor \& Crosby (1987) raise a number of important questions concerning the functions of these follicular polypeptides. Therefore, the objectives of the present experiments were

*Reprint requests to Dr M. F. Smith, 160 Animal Science Research Center. 
to (1) determine whether the secretion of the $M_{\mathrm{r}} 30000$ polypeptide continues after ovulation and luteinization, (2) determine whether luteal secretion of the $M_{\mathrm{r}} 30000$ polypeptide could be regulated by pituitary hormones or $3^{\prime}, 5^{\prime}$-cyclic AMP, (3) determine whether the $M_{\mathrm{r}} 30000$ polypeptide is an inhibin subunit, and (4) obtain an $\mathrm{NH}_{2}$-terminal amino acid sequence for the identification of the protein by sequence identity.

\section{Materials and Methods}

Collection and culture of granulosa cells. Ovaries were collected from Welsh Mountain ewes at slaughter $36 \mathrm{~h}$ after injection (i.m.) of 900 i.u. pregnant mares' serum gonadotrophin (Folligon: Intervet Laboratories Ltd, Cambridge, UK) during the luteal phase. Non-atretic follicles ( $>3 \mathrm{~mm}$ in diameter) were dissected from ovaries at room temperature in Dulbecco's phosphate buffered saline. Granulosa cells were collected, explanted into 4-well plates (Nunclon, Inter Med., Roskilde, Denmark) and cultured in a $\mathrm{CO}_{2}$ incubator $\left(5 \% \mathrm{CO}_{2}\right.$ gas phase) at $38^{\circ} \mathrm{C}$ in Medium 199 (enriched M199) containing Earles salts (Gibco Ltd, Paisley, UK), supplemented with 5\% fetal calf serum and 5\% sheep serum (Sera Lab Ltd, Crawley, Sussex, UK). Once confluence was attained the granulosa cells were washed three times with serum-free Medium 199 in preparation for protein radiolabelling. Luteinization of granulosa cells was characterized by the ability of these cells to secrete predominantly progesterone.

Granulosa cells were also explanted into culture flasks (Nunclon) containing Medium 199 and allowed to grow to confluence. The cells were washed with serum-free medium as previously described and incubated with serum-free Medium 199 which was collected daily for 7 days. After collection, the medium (containing secreted proteins) was dialysed and lyophilized.

Collection and incubation of luteal tissue. Ovaries were collected at slaughter from 20 Welsh Mountain and Clun Forest ewes on Days 3, 7, 10, 13 and $16(\mathrm{~N}=4$ per group) after oestrus (Day 0 ). Corpora lutea were dissected from ovaries at room temperature, cut into 1-mm slices, and washed in serum-free Medium 199 pending radiolabelling.

Action of hormones and drugs on protein secretion. Luteinized granulosa cells and luteal slices were incubated with pituitary hormones (single treatment including NIH-LH-S18, $5 \mu \mathrm{g} / \mathrm{ml}$; NIH-FSH-S12, $2.5 \mu \mathrm{g} / \mathrm{ml}$; and NIH-prolactin$\mathrm{S} 9,20 \mathrm{ng} / \mathrm{ml}$ ) or cholera toxin $(250 \mathrm{ng} / \mathrm{ml})$ for $7 \mathrm{~h}$ (see Methods below) to determine whether either the pattern or rate of protein secretion could be modulated. The cells or luteal slices were radiolabelled as described below. In separate experiments the relative molecular mass of the peptide backbone of the glycosylated $M_{\mathrm{r}} 30000$ molecule was determined by preincubating luteinized granulosa cells in serum-free medium containing tunicamycin $(0,0 \cdot 125,0.25$, $0.5,1.0$ or $2.0 \mu \mathrm{g} / \mathrm{ml}$ ) for $6 \mathrm{~h}$. Thereafter, the preincubation medium was discarded and replaced with medium containing an equivalent amount of tunicamycin in preparation for radiolabelling the cells as described below. Tunicamycin is an antibiotic which inhibits synthesis of $N$-glycosidically linked oligosaccharides (White et al., 1978).

Radiolabelling of cells. Granulosa cells or luteal slices were incubated for $6-7 \mathrm{~h}$ with $\left.0 \cdot 1 \mathrm{mCi} \mathrm{L}-{ }^{35} \mathrm{~S}\right] \mathrm{methionine} / \mathrm{ml}$ (sp. act. $>1000 \mathrm{Ci} / \mathrm{mmol}$ ) in Eagles Minimum Essential Medium which did not contain methionine (MEM Eagle Modified; Flow Laboratories, Irvine, UK). After radiolabelling of cells, the medium was collected, centrifuged ( $500 \mathrm{~g}$ for $5 \mathrm{~min}$ ) to pellet any suspended cells and the supernatant was collected for analysis of secreted polypeptides. Granulosa cells and luteal tissue were also collected, washed with saline, and stored until analysis of intracellular polypeptide synthesis.

Electrophoretic analysis of polypeptides. One-dimensional SDS polyacrylamide gel electrophoresis was used for separation of the labelled polypeptides (secreted and intracellular; Moor et al., 1981). Medium and cells were lyophilized and dissolved in reducing SDS buffer. Incorporation of $\left[{ }^{35}\right.$ S $]$ methionine into TCA-precipitable protein was determined (Moor et al., 1981) and an equal number of counts was placed into each lane of 8 to $15 \%$ linear gradient SDS polyacrylamide gels. Labelled polypeptides were visualized by fluorography by using preflashed Kodak X-Omat film. Densitometric analysis of fluorograms was conducted on a Chromascan 3 (Joyce Lobel, Gateshead, UK).

Production of monoclonal antibodies. Polypeptide $\left(M_{\mathrm{r}} 30000\right)$ was electroeluted from a one-dimensional polyacrylamide gel. Female rats were injected intramuscularly with approximately $10 \mu \mathrm{g}$ polypeptide emulsified in complete Freund's adjuvant. A second subcutaneous injection, containing an equivalent amount of polypeptide emulsified in incomplete Freund's adjuvant, was injected 34 days later. Antibody production was determined 13 days after the booster injection by enzyme-linked immunoabsorbent assay (ELISA) and the immunoblotting technique of Burnette (1981). After a booster injection of $30 \mu \mathrm{g} M_{\mathrm{s}} 30000$ polypeptide, spleen cells from the most reactive rat ( $72 \mathrm{~h}$ after boosting) were fused with the rat myeloma line Y3 Agl.2.3 (Galfre et al., 1979).

Positive cell lines were identified by ELISA and immunoblot and those were single cell cloned to produce a variety of hybridoma cell lines against the $M_{\mathrm{r}} 30000$ polypeptide. One of the monoclonal antibodies was selected for use in this study.

Western blot analysis. Polypeptides from luteinized sheep granulosa cells were reduced (2-mercaptoethanol), separated by one-dimensional SDS polyacrylamide electrophoresis and transferred electrophoretically to nitrocellulose paper. The nitrocellulose paper (transferred proteins) was incubated overnight in $10 \%$ fetal calf serum in 
phosphate-buffered saline $\left(0.05 \%(\mathrm{v} / \mathrm{v})\right.$ Tween) at $4^{\circ} \mathrm{C}$ to block non-specific binding sites. The nitrocellulose was cut into strips (3-4 mm) which were incubated with PBS-Tween (Control), rabbit anti porcine 1-26 $\alpha$ chain inhibin antiserum (1/1000 dilution in PBS-Tween; gift from Dr A. S. McNeilly, MRC Reproductive Biology Unit, Edinburgh EG3 9EW, UK, to Dr P. Wooding, AFRC, Babraham, Cambridge), or monoclonal antibody against the $M_{\mathrm{r}} 30000$ polypeptide (undiluted culture medium) for $18 \mathrm{~h}$ at room temperature. The strips were washed 5 times (10 min each) in PBS-Tween and incubated with goat anti-rabbit or anti-rat immunoglobulin conjugated to alkaline phosphatase at $1 / 1000$ dilution in PBS containing $10 \%$ fetal calf serum. Strips were washed 5 times $(5 \mathrm{~min}$ each) in veronal acetate buffer ( $0.15 \mathrm{M}$-sodium barbitone; $\mathrm{pH} 9.6)$ and transferred to veronal acetate buffer containing 5 bromo-4 chloro-indoyl phosphate $(5 \mathrm{mg} / \mathrm{ml}$ in dimethyl formamide) and nitroblue tetrazolium $(1 \mathrm{mg} / \mathrm{ml}$ in veronal acetate buffer).

$\mathrm{NH}_{2}$-terminal amino acid sequence. Protein secreted by luteinized granulosa cells was separated by one-dimensional SDS polyacrylamide gel electrophoresis. Proteins were electrophoretically transferred to polyvinylidene difluoride membrane (Matsudaira, 1987) and the $M_{\mathrm{r}} 28000-30000$ band was subjected to microsequencing. Gas-phase Edman degradation (Applied Biosystems $470 \mathrm{~A}$ ) was utilized to obtain an $\mathrm{NH}_{2}$-terminal amino acid sequence.

\section{Results}

\section{Polypeptide secretion during the oestrous cycle}

The first experiment was conducted to determine whether the $M_{\mathrm{r}} 30000$ polypeptide was synthesized and secreted by luteal tissue. Although there were slight differences, the overall pattern of polypeptides, and in particular the $M_{\mathrm{r}} 30000$ polypeptides secreted by luteal slices were similar to those secreted by luteinized ovine granulosa cells (Fig. 1). The amount of $M_{\mathrm{r}} 30000$ polypeptide which was released did not appear to vary during the oestrous cycle and its absence from intracellular polypeptide profiles indicated that it was rapidly released by luteal tissue.
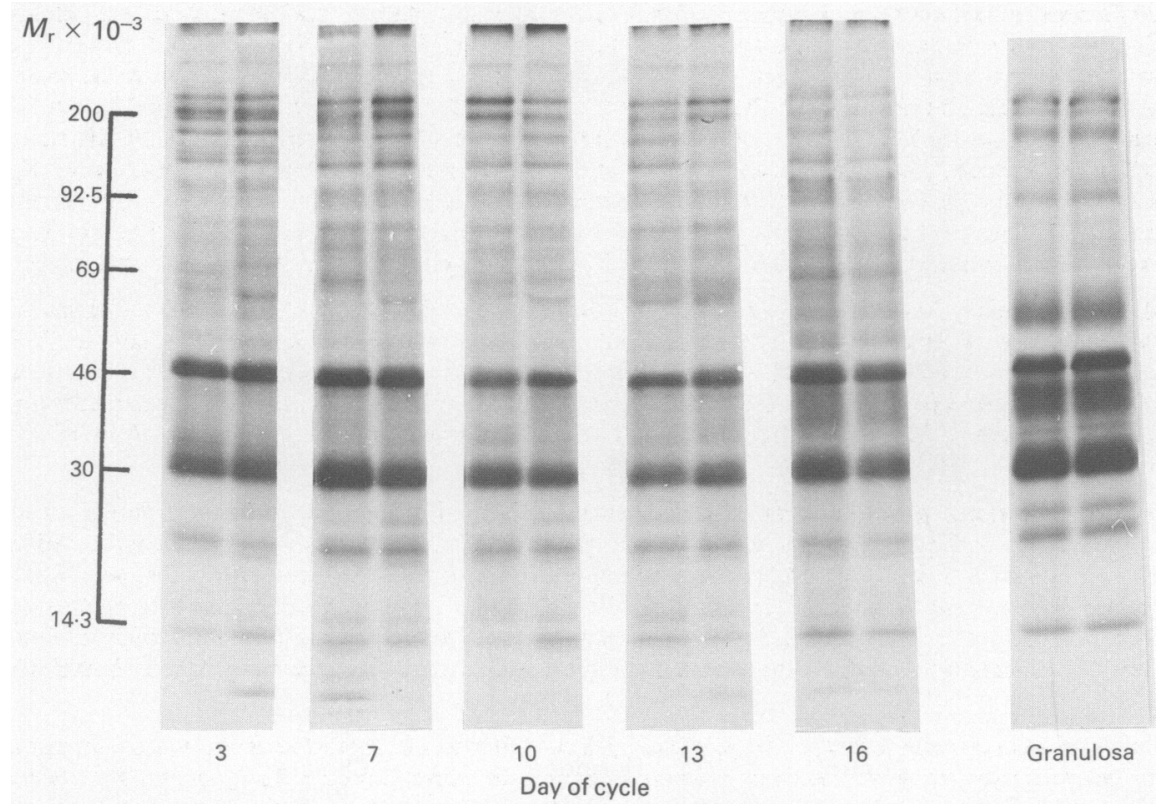

Fig. 1. Fluorograph of a one-dimensional SDS-polyacrylamide gel showing changes in patterns of ovine luteal polypeptide secretion into medium on Days 3-16 after oestrus (Day $0=$ oestrus; each lane represents a different animal). Labelled polypeptides secreted by luteinized ovine granulosa cells are also presented.

Other major polypeptides secreted throughout the luteal phase included molecules with an $M_{\mathrm{r}}$ of 14000,25000 and 46000 . The mean percentage of polypeptide as measured by densitometry, represented by the $M_{\mathrm{r}} 14000,25000,30000$ and 46000 polypeptides was 3, 9, 24 and $23 \%$, respectively. 
(a)

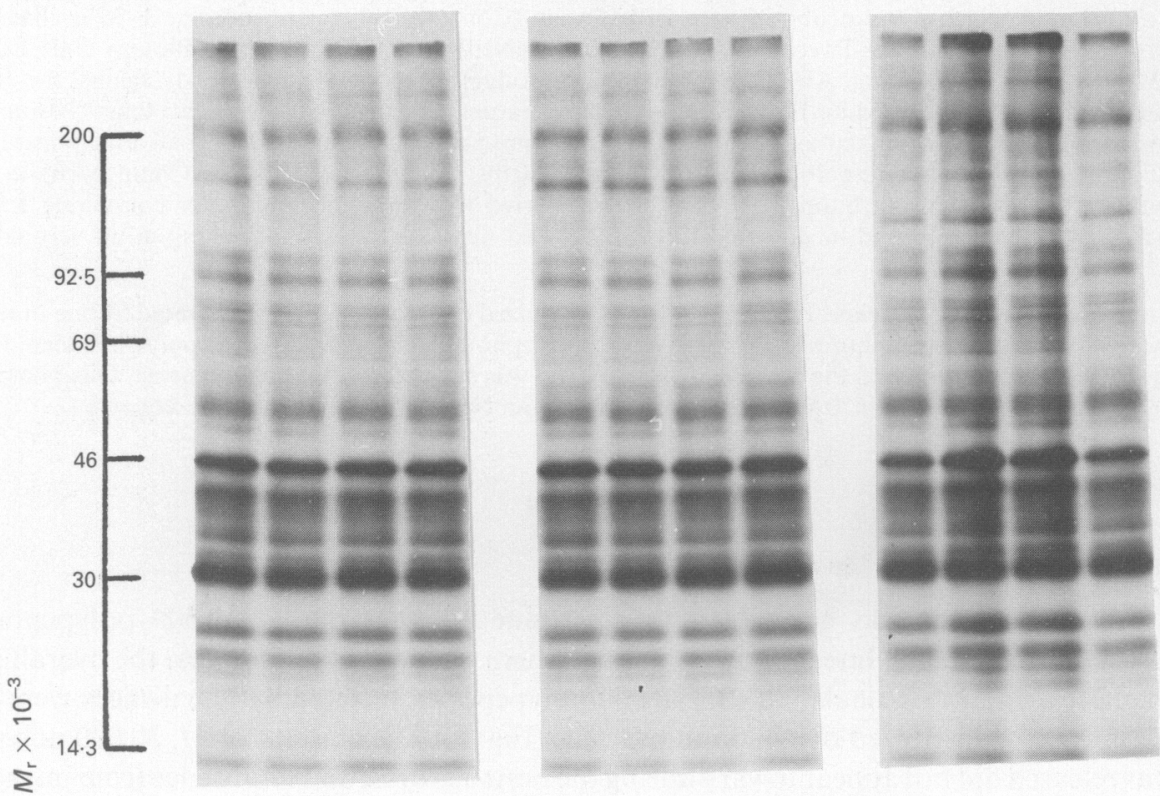

(b)

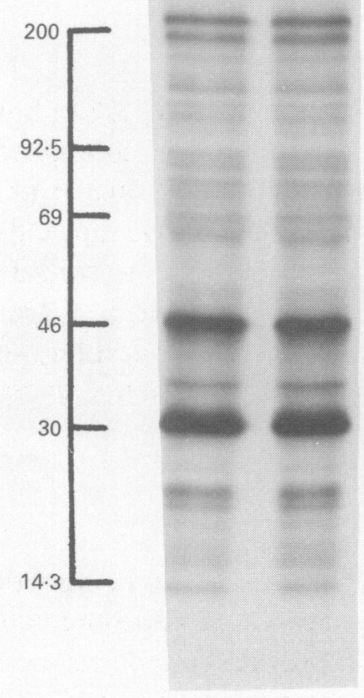

Control

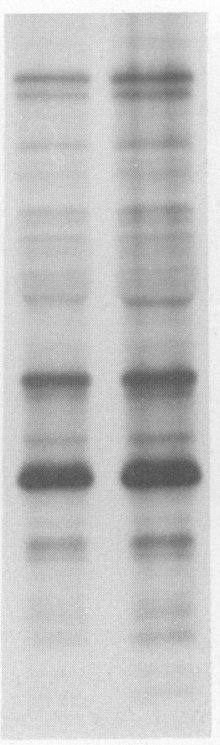

Hormone

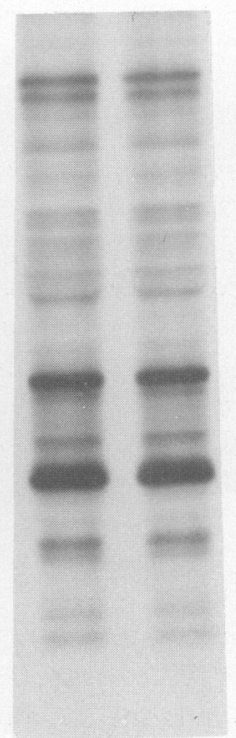

Cholera

toxin

Fig. 2. Fluorograph of a one-dimensional SDS-polyacrylamide gel showing the effect of pituitary hormones (LH, FSH, prolactin) and cholera toxin (activates adenylate cyclase) on pattern of polypeptide secretion by (a) luteinized ovine granulosa cells and (b) ovine luteal tissue (adjacent lanes within treatment are replicates).

\section{Effect of pituitary hormones and cholera toxin}

Addition of hormones (LH, FSH and prolactin) or cholera toxin did not alter the pattern of polypeptide secretion by luteinized granulosa cells (Fig. 2a) or luteal tissue (Fig. 2b; Day 10 after 

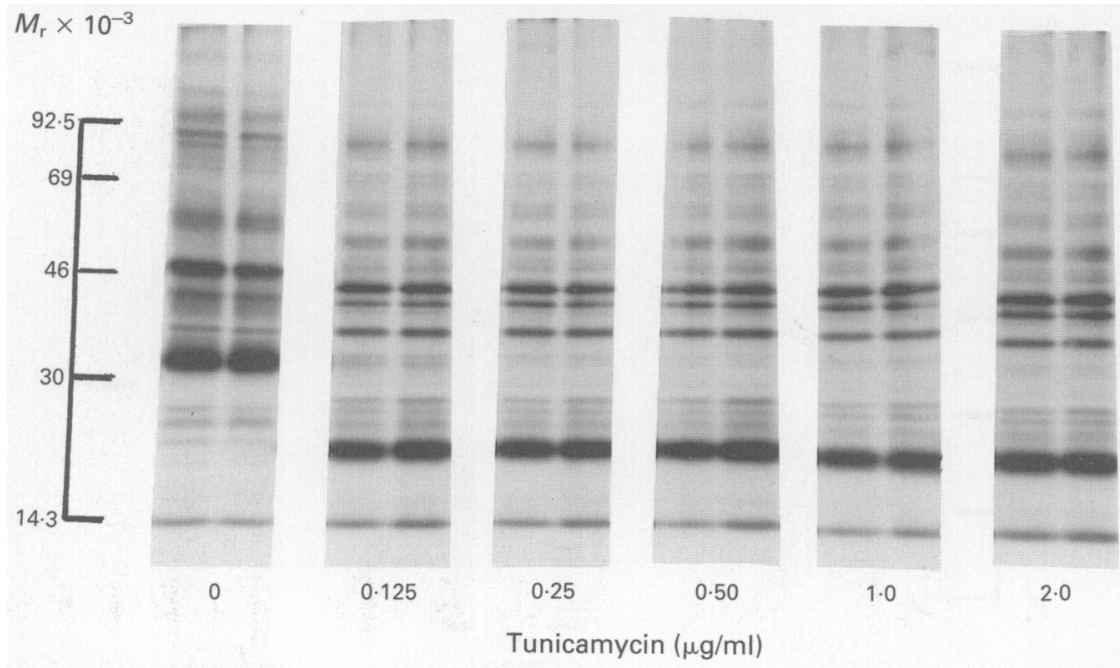

Fig. 3. Fluorograph of a one-dimensional SDS-polyacrylamide gel showing the effect of different concentrations of tunicamycin on the pattern of polypeptide secretion by luteinized ovine granulosa cells (adjacent lanes within treatment are replicates).

oestrus). The only exception was a polypeptide $\left(M_{\mathrm{r}} 120000\right)$ which was released by luteinized granulosa cells after stimulation with cholera toxin.

\section{Effect of tunicamycin}

The $M_{\mathrm{r}} 30000$ polypeptide was shown to be glycosylated (Moor \& Crosby, 1987); however, the degree of glycosylation was not determined. Therefore a third experiment was conducted to determine the effects of tunicamycin on the relative molecular mass of the $M_{\mathrm{r}} 30000$ polypeptide. Incubation of luteinized granulosa cells with tunicamycin decreased the relative molecular mass of the polypeptide to 20000 (Fig. 3), but this reduction was not affected by the concentration of tunicamycin $(0.125-2.0 \mu \mathrm{g} / \mathrm{ml})$. A polypeptide product $\left(M_{\mathrm{r}} 32000\right)$ remained after tunicamycin treatment and there may be more than one polypeptide present at this molecular weight. The relative molecular mass of several other secreted proteins was also reduced but not as dramatically as that of the $M_{\mathrm{r}} 30000$ polypeptide.

\section{Western blot analysis for inhibin}

The fourth experiment was conducted to determine whether the $M_{\mathrm{r}} 30000$ polypeptide was an inhibin subunit. Protein collected from luteinized granulosa cells was treated with 2-mercaptoethanol to reduce disulphide bonds and separated on a one-dimensional polyacrylamide gel. A polyclonal antibody to the $\alpha$ subunit of inhibin (rabbit anti-porcine 1-26 $\alpha$ chain inhibin) bound specifically to $M_{\mathrm{r}} 22000$ and 67000 polypeptides but not to the $M_{\mathrm{r}} 30000$ polypeptides; the monoclonal antibody directed against the $M_{\mathrm{r}} 30000$ polypeptide specifically bound $M_{\mathrm{r}} 30000$ polypeptides (Fig. 4). Detection of higher molecular weight forms of ovine inhibin has been reported (Findlay \& Clarke, 1987). Two separate bands were present in the lanes probed with monoclonal antibody directed against $M_{\mathrm{r}} 30000$ polypeptide.

\section{$\mathrm{NH}_{2}$-terminal amino acid sequence}

The $\mathrm{NH}_{2}$-terminal sequence of the first 25 amino acids is shown in Fig. 5. The $M_{\mathrm{r}} 30000$ polypeptide had $68 \%$ sequence identity with a human tissue inhibitor of metalloproteinase. 


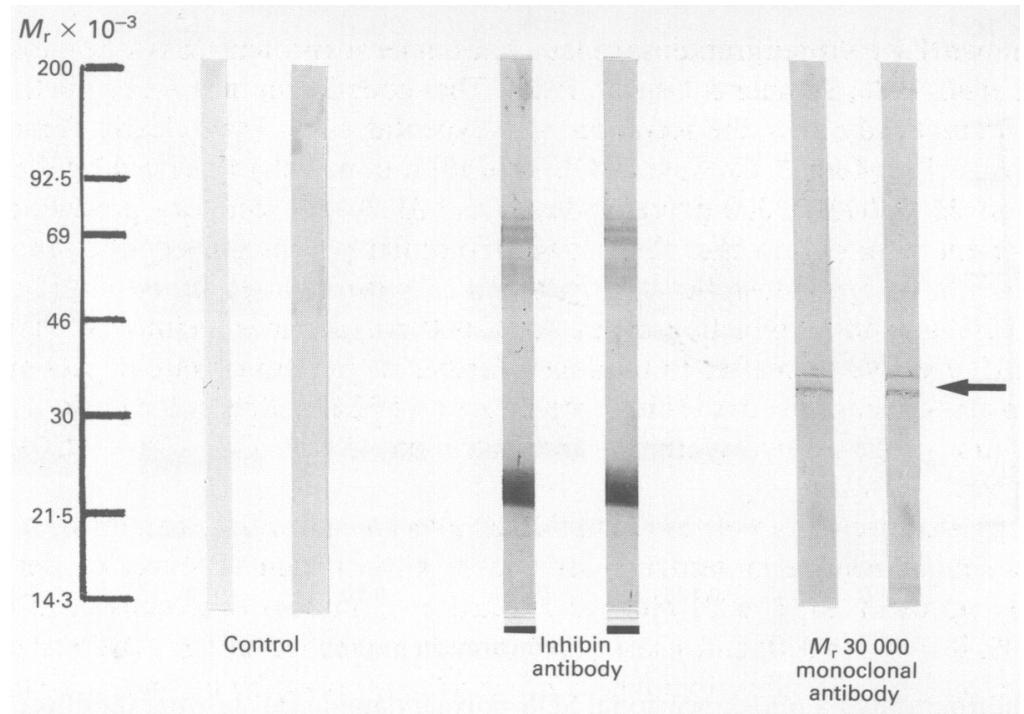

Fig. 4. Western blot analysis of protein secreted (in vitro) by luteinized ovine granulosa cells. Equal amounts of protein were added to each lane and adjacent lanes within treatment are replicates. Nitrocellulose strips were incubated with normal rabbit serum (Control), rabbit anti-porcine 1-26 $\alpha$ chain inhibin antiserum (Inhibin antibody) or a monoclonal antibody directed against the $M_{\mathrm{r}} 30000$ polypeptide. Two separate bands are present (arrow) in the lanes probed with monoclonal antibody directed against the $M_{\mathrm{r}} 30000$ molecules.

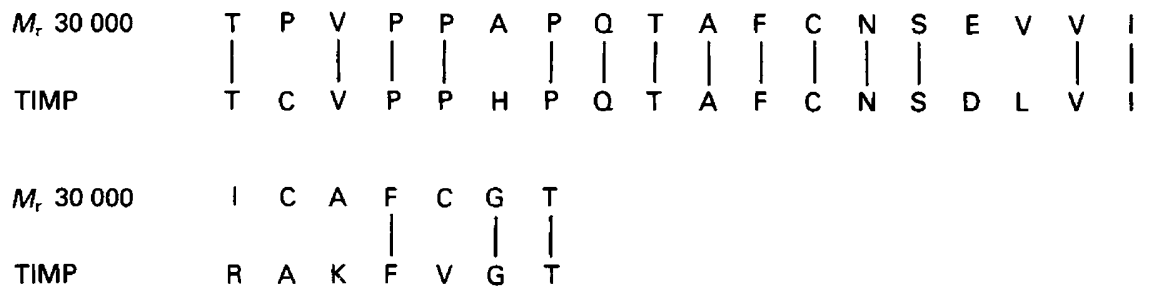

Fig. 5. Sequence identity between the $\mathrm{NH}_{2}$-terminal amino acid sequences of the $M_{\mathrm{r}} 30000$ polypeptide and a human tissue inhibitor of metalloproteinase (TIMP). Amino acids are expressed as single letters.

\section{Discussion}

The emphasis in studies on the corpus luteum has shifted recently from the regulation of progesterone synthesis and secretion (Niswender \& Nett, 1988) to the characterization, regulation and physiological role of luteal peptides and proteins (Schams, 1987, 1989). However, with the exception of oxytocin, relaxin and inhibin, very little information has so far been published on the secretion of other luteal proteins. This is addressed in our experiments, the results of which show that sheep luteal cells secrete a variety of polypeptides throughout the luteal phase and during luteolysis. Two interesting general points emerge from these studies. First, it is clear that the secretory polypeptides from luteal tissue are largely similar to those secreted by luteinized sheep granulosa cells. Secondly, although the steroidogenic capacity of the corpus luteum is markedly reduced by Day 16 (Diekman et al., 1978), this is not paralleled by changes in the pattern of polypeptides which remain remarkably constant throughout the cycle. 
It is well known that cultured granulosa cells secrete numerous proteins (Savion \& Gospodarowicz, 1980; Knecht et al., 1986; Skinner \& Osteen, 1988). That gonadotrophins acting via transcriptional mechanisms dramatically alter the secretion of polypeptides has been clearly demonstrated for sheep granulosa cells (Moor \& Crosby, 1987). This alteration is characterized by the switch from the secretion of $M_{\mathrm{r}} 46000-60000$ polypeptides to the $M_{\mathrm{r}} 30000$ secretory product after the $\mathrm{LH}$ surge. Our present results show that these lower molecular weight polypeptides are secreted not only by the membrana granulosa but also by luteal cells throughout the ensuing oestrous cycle. Although LH initiates the production of the $M_{\mathrm{r}} 30000$ polypeptides, neither pituitary hormones nor cyclic AMP are able thereafter to modulate further its pattern or rate of secretion by luteal cells. This is in marked contrast to the luteotrophic action of LH and its cyclic nucleotide intracellular mediator on progesterone synthesis and secretion (Rothchild, 1981; Niswender, 1981; Niswender \& Nett, 1988).

Inhibin suggested itself as an obvious candidate molecule in our first identification experiments because of its similar relative molecular mass and its known cellular source of synthesis. Ovine inhibin is a glycoprotein $\left(M_{\mathrm{r}} 32000\right)$ which is secreted by granulosa cells, consists of two subunits ( $\alpha=M_{\mathrm{r}} 21000, \beta=M_{\mathrm{r}} 16000$ ) and selectively suppresses secretion of FSH (Leversha et al., 1987; Findlay \& Clarke, 1987). Inhibin is known to be secreted (in vitro) by bovine and ovine luteinized granulosa cells (Luck et al., 1989; Campbell, 1989), but inhibin secretion by luteal tissue has been controversial. Although granulosa cells are considered the primary source of inhibin, luteal tissue of humans (Davis et al., 1987), rats (Davis et al., 1986), sheep (Tsonis et al., 1988) and cattle (Juengel et al., 1990) also contains inhibin. Inhibin a subunit mRNA has been detected in human (Davis et al., 1987), rat (Davis et al., 1986) and bovine (Juengel et al., 1990) luteal tissue, but other investigators have failed to detect inhibin $\alpha$ subunit mRNA in the luteal tissue of rats (Woodruff $e t$ al., 1988), sheep (Rodgers et al., 1989) or cattle (Rodgers et al., 1989). Clearly the $M_{\mathrm{r}} 30000$ polypeptide is not inhibin since the molecular weight of the polypeptide did not decrease under reducing conditions (2-mercaptoethanol) and the inhibin antiserum did not detect the $M_{\mathrm{r}} 30000$ polypeptide by Western blot analysis.

Monoclonal antibody production and microsequencing were used in the second series of experiments on the identification of the $M_{\mathrm{r}} 30000$ secretory polypeptide. In two separate laboratories (Babraham and University of Missouri) $\mathrm{NH}_{2}$-terminal amino acid sequences revealed that a close sequence identity exists between the $M_{\mathrm{r}} 30000$ polypeptides and a human tissue inhibitor of metalloproteinase (TIMP; Docherty et al., 1985). In addition to similarities in $\mathrm{NH}_{2}$-amino acid sequence identity, the secreted polypeptide and metalloproteinase inhibitor (TIMP) share similar physicochemical properties. TIMP normally has a molecular weight ranging from 28000 to 30000 and the molecular weight of TIMP secreted into medium by cells cultured with tunicamycin was 20000 (Murphy \& Werb, 1985). The unglycosylated form of the $M_{\mathrm{r}} 30000$ glycoprotein was also $M_{\mathrm{r}} 20000$. Metalloproteinase inhibitor activity has been detected in human ovarian follicular fluid (Curry et al., 1988) and rat granulosa cell-conditioned medium (Slackman et al., 1986; Mann et al., 1990). Furthermore, stimulation of rat granulosa cells with LH or a phorbol ester increased the secretion of metalloproteinase inhibitor activity (Mann et al., 1990). The highest level of expression of TIMP mRNA was detected in the corpora lutea of mice (Nomura et al., 1989).

Metalloproteinases are metal-dependent enzymes which are capable of degrading proteinaceous components of the extracellular matrix. The regulation of extracellular matrix turnover is a precisely controlled process which is designed to maintain normal cellular organization (Mullins \& Rohrlich, 1983). Krane (1985) proposed the following three mechanisms by which turnover of the extracellular matrix may be regulated: (1) rate of latent enzyme synthesis, (2) proteolytic activation of latent enzymes, and (3) synthesis of specific protease inhibitors. Tissue inhibitors of metalloproteinases (TIMP) form irreversible inactive complexes with metalloproteinases and thereby regulate the extracellular activity of these proteolytic enzymes. Metalloproteinase inhibitors are reported to have an important role in the regulation of collagenase activity within the extracellular 
spaces of bone (Cawston et al., 1981), skin (Stricklin \& Welgus, 1983) and cartilage (Dean \& Woessner, 1984).

The preovulatory gonadotrophin surge increases the synthesis of proteolytic enzymes (i.e. plasminogen activator and collagenase) which are reported to be involved in proteolytic degradation of the preovulatory follicular wall (Lipner, 1988). Although collagenase activity is known to increase following LH stimulation there is very little information on the regulation of collagenolysis within the follicular wall. In fibroblasts (Murphy et al., 1985) the secretion of collagenase and inhibitors of collagenase increased simultaneously. Therefore, metalloproteinase inhibitors may have an important role in the regulation of collagenolysis after the gonadotrophin surge and may continue to be involved in cellular remodelling during the luteal phase.

This paper is a contribution from the Missouri Agricultural Experiment Station. Journal Series No. 11,245. This research was partly supported by the John E. Fogarty Senior International Fellowship Program of the United States Public Health Services.

We thank Dr G. W. Butcher and L. Richardson for assistance in developing monoclonal antibodies; and Dr R. A. P. Harrison, Dr R. M. Roberts and N. Clarke for helpful suggestions and assistance.

\section{References}

Burnette, W.N. (1981) “Western Blotting:” electrophoretic transfer of proteins from sodiumdodecylsulphatepolyacrylamide gels to unmodified nitrocellulose and radiographic detection with antibody and radioiodinated protein A. Analyt. Biochem. 112, 195-203.

Campbell, B.K. (1989) Inhibin, oestradiol and progesterone production by ovine granulosa cells in vitro. $J$. Reprod. Fert., Abstr. Ser. 3, p. 24, abstr.

Cawston, T.E., Galloway, W.A., Mercer, E., Murphy, G. \& Reynolds, J.J. (1981) Purification of rabbit bone inhibitor of collagenase. Biochem. J. 195, 159-165.

Curry, T.E., Jr, Sanders, S.L., Pedigo, N.G., Estes, R.S., Wilson, E.A. \& Vernon, M.W. (1988) Identification and characterization of metalloproteinase inhibitor activity in human ovarian follicular fluid. Endocrinology 123, 1611-1618.

Davis, S.R., Dench, F., Nikolaidis, I., Clements, J.A., Forage, R.G., Krozowski, Z. \& Burger, H.G. (1986) Inhibin A-subunit gene expression in the ovaries of immature female rats is stimulated by pregnant mare serum gonadotropin. Biochem. Biophys. Res. Commun. 138, 1191-1194.

Davis, S.R., Krozowski, Z., McLachlan, R.I. \& Burger, H.G. (1987) Inhibin gene expression in the human corpus luteum. J. Endocr. 115, R21-R23.

Dean, D.D. \& Woessner, J.F. (1984) Extracts of human articular cartilage contain an inhibitor of tissue metalloproteinases. Biochem. J. 218, 277-280.

Diekman, M.A., O'Callaghan, P., Nett, T.M. \& Niswender, G.D. (1978) Validation of methods and quantification of luteal receptors for LH throughout the estrous cycle and early pregnancy in ewes. Biol. Reprod. 19, 999-1009.

Docherty, A.J.P., Lyons, A., Smith, B.J., Wright, E.M., Stephens, P.E. \& Harris, T.J.R. (1985) Sequence of human tissue inhibitor of metalloproteinases and its identity to erythroid-potentiating activity. Nature, Lond. 318, 66-69.
Findlay, J.K. \& Clarke, I.J. (1987) Regulation of the secretion of FSH in domestic ruminants. J. Reprod. Fert., Suppl. 34, 27-37.

Galfre, G., Milstein, C. \& Wright, B. (1979) Rat $\times$ rat hybrid mylomas and a monoclonal anti-Fd portion of mouse IgG. Nature, Lond. 222, 131-133.

Juengel, J.L., Imakawa, K., Farin, P.W. \& Garverick, H.A. (1990) Detection of mRNA for inhibin $\alpha$ and $\beta$ subunits in bovine ovarian tissues and effect of in vivo administration of GnRH. Biol. Reprod. 42 (Suppl. 1), 174, abstr.

Knecht, M., Shinohara, O. \& Catt, K.J. (1986) Biosynthesis of cellular and secreted proteins during follicle-stimulating hormone-induced granulosa cell differentiation. Endocrinology 119, 1388-1396.

Krane, S.M. (1985) The turnover and degradation of collagen. In Fibrosis (CIBA Fdn Symp. No. 114), pp. 97-110. Pitman Publishing, London.

Leversha, L.J., Robertson, D.M., de Vos, F.L., Morgan, F.J., Hearn, M.T.W., Wettenhall, R.E.H., Findlay, J.K., Burger, H.C. \& de Kretser, D.M. (1987) Isolation of inhibin from ovine follicular fluid. $J$. Endocr. 113, 213-221.

Lipner, H. (1988) Mechanism of mammalian ovulation. In The Physiology of Reproduction, pp. 447-488. Eds E. Knobil \& J. Neill. Raven Press. New York.

Luck, M.R., Rodgers, R.J. \& Findlay, J.K. (1989) Expression of inhibin by bovine granulosa cells during spontaneous luteinization in culture. J. Reprod. Fert., Abstr. Ser. 3, p. 23, abstr.

Mann, J.S., Clark, M.R. \& Curry, T.E., Jr (1990) Effect of gonadotropins and growth factors on metalloproteinase inhibitor activity from rat granulosa cells. Biol. Reprod. 42 (Suppl. 1), 121, abstr.

Matsudaira, P. (1987) Sequence from picomole quantities of proteins electroblotted onto polyvinylidene difluoride membranes. J. biol. Chem. 262, 10035-10038. 
Moor, R.M. \& Crosby, I.M. (1987) Cellular origin, hormonal regulation, and biochemical characteristics of polypeptides secreted by Graafian follicles of sheep. J. Reprod. Fert. 79, 469-483.

Moor, R.M., Osborn, J.C., Cran, D.G. \& Walters, D.E. (1981) Selective effect of gonadotrophins on cell coupling, nuclear maturation and protein synthesis in mammalian oocytes. J. Embryol. exp. Morph. 61, 347-365.

Mullins, D.E. \& Rohrlich, S.T. (1983) The role of proteases in cellular invasiveness. Biochem. Biophys. Acta $695,177-214$.

Murphy, G. \& Werb, Z. (1985) Tissue inhibitor of metalloproteinases. Identification of precursor forms synthesized by human fibroblasts in culture. Biochem. Biophys. Acta 839, 214-218.

Murphy, G., Reynolds, J.J. \& Werb, Z. (1985) Biosynthesis of tissue inhibitor of metalloproteinases by human fibroblasts in culture. J. biol. Chem. 260, 3079-3083.

Niswender, G.D. (1981) Response of the corpus luteum to luteinizing hormone. Environmental Health Perspectives 38, 47-50.

Niswender, G.D. \& Nett, T.M. (1988) The corpus luteum and its control. In The Physiology of Reproduction, pp. 489-525. Eds E. Knobil \& J. Neill. Raven Press, New York.

Nomura, S., Hogan, B.L., Wills, A.J., Heath, J.K. \& Edwards, D.R. (1989) Developmental expression of tissue inhibitor of metalloproteinase (TIMP) RNA. Development 105, 575-583.

Rodgers, R.J., Stuchberg, S.J. \& Findlay, J.K. (1989) Inhibin mRNAs in ovine and bovine ovarian follicles and corpora lutea throughout the estrous cycle and gestation. Molec. cell. Endocrinol. 62, 95-101.

Rothchild, I. (1981) The regulation of the mammalian corpus luteum. Recent Prog. Horm. Res. 37, 183-298.
Savion, N. \& Gospodarowicz, D. (1980) Patterns of cellular peptide synthesis by cultured bovine granulosa cells. Endocrinology 107, 1798-1807.

Schams, D. (1987) Luteal peptides and intercellular communication. J. Reprod. Fert., Suppl. 34, 87-99.

Schams, D. (1989) Ovarian peptides in the cow and sheep. J. Reprod. Fert., Suppl. 37, 225-231.

Skinner, M.K. \& Osteen, K.G. (1988) Developmental and hormonal regulation of bovine granulosa cell function in the preovulatory follicle. Endocrinology 123, 1668-1675.

Slackman, R.L., Curry, T.E., Koos, R.D. \& Le Maire, W.J. (1986) A neutral metalloprotease inhibitor from rat granulosa cells. Endocrinology 118 (Suppl.), 222, Abstr. 764.

Stricklin, G.P. \& Welgus, H.G. (1983) Human skin fibroblast collagenase inhibitor. J. biol. Chem. 258, 12252-12258.

Tsafriri, A. (1988) Local nonsteroidal regulators of ovarian function. In The Physiology of Reproduction, pp. 527-565. Eds E. Knobil \& J. Neill. Raven Press, New York.

Tsonis, C.G., Baird, D.T., Campbell, B.K., Leask, R. \& Scaramuzzi, R.J. (1988) The sheep corpus luteum secretes inhibin. J. Endocr. 116, R3-R5.

White, A., Handler, P., Smith, E.L., Hill, R.L. \& Lehman, I.R. (1978) Carbohydrate metabolism II. In Principles of Biochemistry, pp. 477-531. Eds J. D. Jeffers, A. Macnow, M. LaBarbera \& T. Armstrong. McGraw Hill, New York.

Woodruff, T.K., D'Agostino, J., Swartz, N.B. \& Mayo, K.E. (1988) Dynamic changes in inhibin messenger RNAs in rat ovarian follicles during the reproductive cycle. Science, NY 239, 1296-1299.

Received 12 July 1990 